\title{
セメント系押出成形部材のプロセス制御システムの開発 \\ A DEVELOPMENT ON PROCESS CONTROL SYSTEMS FOR EXTRUSION MOULDING OF CEMENTITIOUS COMPONENTS
}

\author{
馬場明生*1, 守 明子*2, 堀口昌利*3 \\ Akio BABA, Akiko MORI and Masatoshi HORIGUCHI
}

\begin{abstract}
Process control for the extrusion moulding of cementitious components is more difficult than that of cast moulding because the rheological factors for the moulding are more complicated. This paper deals with a development of total process control systems including material and machinery technologies. Firstly, the process control flow of one way was proposed. Secondly, the equations which show the laws at each step of flow were checked based on experimental data with various materials, mix proportions, die opening geometries and barrel diameters. According to the good coordination between calculated values and experimental ones, the random accessible total system was developed.
\end{abstract}

Keywords: process control, cementitious components, extrusion moulding, extruding pressure, extruding velocity, process control system

プロセス制御, セメント系部材, 押出成形, 押出成形圧力, 押出成形速度, プロセス制御システム

\section{1. はじめに}

押出成形により製造されたセメント系部材は，少ない水量 で，しかも，機械力を用いて材料中の空気を排除しながら製 造されるので，材料組織が緻密化され，それ故に型枠成形， 抄造成形，遠心成形などにより製造される部材と比較すると， 高い曲げ比強度と耐久性とにおいて他の追随を許さない。ま た，押出成形機先端に設置するダイ (口金) を選択すること により，用途に応じた空洞構造をも含む適切な各種断面形状 の部材が容易に得られ，しかも，その製造は連続的である。 したがって，セメント系押出成形部材は，建築生産における 省人化・情報化に対応しうる部材として, その生産量は増加 の一途をたどっている。

しかしながら, 著者らの最近の研究により, 用途に適合し た断面形状と安定した品質の部材を製造するための材料技術 の観点からの基礎的な法則は明確になったものの, セメント 系押出成形部材の製造工場ではシステム化した機械，すなわ ち機械系の使用を前提としているので，材料技術と機械技術 との観点からの総合的なプロセス制御システムの確立が急務 である。

著者らは，材料条件を種々変化させた実験を実施し，その
結果に基づいて，セメント系材料を押出成形するときの成形 圧力および速度を予測する方法に関する基本的な法則を明確 にした。さらに，ダイ開口形状およびバレル径という機械条 件を変化させた実験を実施し, 成形圧力は材料の塑性加工の 度合いにより決定されること, ならびに材料条件と機械条件 を変化させたときの成形速度の予測方法等を明らかにした。

ここでは，これらの成果をふまえて，機械条件と材料条件 とを任意に変化させた場合における総合的なプロセス制御シ ステム, ならびに押出成形機稼働時において操作点の変更を 可能とするオンライン修正技術のための基本的な要素技術を 提案する。

$\begin{array}{ll}\text { 本論文で用いた記号 } \\ \mathrm{W}^{*} & \text { water content ratio }(-) \\ \mathrm{S} / \mathrm{C} & \text { sand cement ratio }(-) \\ \sigma & \text { normal stress of fresh mixtures in tapered barrels ( MPa }) \\ \tau & \text { shear stress of fresh mixtures in tapered barrels }(\mathrm{MPa}) \\ \mathrm{Q} & \text { conveying rate per revolution }\left(\mathrm{cm}^{3} / \mathrm{r}\right) \\ \mathrm{V} & \text { extruding velocity }(\mathrm{cm} / \mathrm{min}) \\ \mathrm{P} & \text { extruding pressure }(\mathrm{MPa}) \\ \mathrm{P}_{\text {max }} & \text { extruding pressure when closed die openings ( MPa }) \\ \mathrm{t}_{\mathrm{c}} & \text { effective thickness of die openings }(\mathrm{cm})\end{array}$

*1 山口大学: 工学部 感性デザイン工学科 教授・エ博

*2 通商産業省 J業技術院 九州工“業技術研究所 主任研究官・博士 (工学)

*3 昭和電工株式会社 総合研究所川崎研究窒 主務
Prof., Dept. of KANSEI Design Engineering, Faculty of Engineering, Yamaguchi University, Dr. Eng.

Senior Research Scientist, Kyushu National Industrial Research Institute, AIST, MITI, Dr. Eng.

Researcher, SHOWA DENKO K.K. 
$t: 0 \quad$ effective thickness of barrel openings ( $\mathrm{cm}$ )

A sectional area of die openings $\left(\mathrm{cm}^{2}\right)$

A o sectional area of barrel openings $\left(\mathrm{cm}^{2}\right)$

$\mathrm{n} \quad$ rotational frequency of screws ( $\mathrm{rpm}$ )

$\zeta \quad$ die barrel opening ratio ( $\left.\mathrm{A} / \mathrm{A}_{0}\right)$

$r \quad$ inner radius of barrels $(\mathrm{cm})$

$\mathrm{t}$ thickness of die openings ( $\mathrm{cm})$

$\mathrm{w} \quad$ width of die openings $(\mathrm{cm})$

$\beta \quad$ sectional hollow ratio of products $(-)$

\section{2. 既往の研究}

セメント系材料をある機械条件において押出成形するとき の成形圧力および速度を予測する方法に関連して，著者らは 以下の法則を明らかにした。

フレッシュな材料の塑性加工進行中において，ダイとバレ ルとの間に存在するテーパードバレル内の垂直応力 $(\sigma)$ と 剪断強度 $(\tau)$ との関係は, 物質の種類および調合という材 料条件にかかわりなく次式の関係となる [1]。”

$$
\tau=\mathbf{a} \cdot \sigma^{\mathrm{b}}
$$

ここで，a および $\mathrm{b}$ は機械条件に依存する定数である。 Equation(1) は，押出成形に用いる材料が，これまで押出成 形が適用されているプラスチックや粘土様材料（Clay-like materials）等とは異なり, 剪断強度とその垂直応力依存性と の組合せが優先する粒子分散型複合材料であることを示して おり，「塑性加工則」と言うこととする。また，押出成形を 実施する前に成形の可否および難易度を予測するために，粘 着力および内部摩擦係数を 2 変数インディケータとして提案 し，それらを求めるための簡易型一面剪断試験方法を提案し た [2]。

つぎに，スクリュー 1 回転当たりの材料の搬送量 ( Q ) は, 材料条件にかかわらず押出成形圧力（P) と次式の関係とな る [1]。

$$
Q=c \cdot P^{-d}
$$

ここで， $\mathrm{c} お よ ひ ゙ \mathrm{~d}$ も機械条件に依存する定数である。

Equation(2) は生産性に直結した押出成形速度を求めるた めの基本的な式であり，「生産効率則」と言うこととする。

一方，機械条件としてダイ開口形状およびバレル径を変化 させたときの成形圧力および速度について一連の実験を行い， 機械条件の押出成形性に及ぼす影響に関して以下に述べる基 礎的な知見を得た [3-5]。

機械条件を変化させた場合, 成形圧力はバレル部からダイ 部における材料の塑性加工の度合い (有効厚さ; $\mathrm{t} 。$ ) との関 係は次式で表すことができる。

$$
\frac{P}{P_{\max }}+\frac{t_{c}}{t_{c 0}}=1
$$

Equation(3) はダイ開口形状とバレル径との関係において 成形圧力を求める式であり，「有効厚さ則」と言うこととす る。

さらに，機械条件を変化させた場合，成形速度 $(\mathrm{V})$ とバ レル断面積に対するダイ開口断面積の割合 (ダイバレル開口

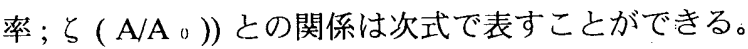

$$
\mathrm{V}=\mathrm{n} \cdot \mathrm{Q} /\left(\zeta \cdot \mathrm{A}_{0}\right)
$$

Equation(4) はダイ開口形状とバレル径との関係において 成形速度を求める式であり，「成形速度則」と言うこととす る。

ここで，Q Q は押出成形機が二定の場合，材料条件のうち 水量比*1 $\left(\mathrm{W}^{*}\right)$ によって決定され，その関係は次式のように なる。

$$
\mathrm{Q}=\mathrm{e} \cdot \mathrm{W}^{*}+\mathrm{f}
$$

ここで， e および $\mathrm{f} は$ 使用するバレル径および物質によっ て決まる定数である。

本論文では，物質・調合という多様な材料条件と，バレル ならびに部材断面形状を決定するダイ開口形状という機械条 件とに関して，以下のような総合的なプロセス制御システム を提案する。

1) 材料条件および機械条件を与えることにより，操作点で ある押出成形圧力と速度との関係を決定することができる。 2) 任意の要素システムからランダムにアクセスすることが できる。

3) オンライン状態で所望の操作点へと修正することができ る。

*1 水量比とは，使用材料のうちセメント・絒骨材・水の総質量に対する水の質 量比とする。コンクリートの場合，通常，材料の調合は単位容積あたりの質量で 表すが、ここでは部材の製造管理の立場から質量による表現を採る。

\section{3. 要素技術の提案}

\section{1 提案の概要}

既往の研究成果を基に総合的なプロセス制御システムの単 一方向のフローを描くと Figure 1 のようになる。このフロ 一は, フレッシュな材料の剪断特性から始まり操作点の決定 に至るまでの基本的な流れを示している。現実の工場操作に おいてはフローの任意の位置にアクセスできることが求めら れるので，各ステップの要素を明確化にし，一方向の流れで はなく包括的な相互関係について明確にする必要がある。す なわち, 各ステップ毎の要素の関連要因および成立する法則 を明確にすると同時に，要素間の定量的関連を視覚的にも明 らかにする必要がある。そのためには，各要素における法則 に加えてその適用範囲が明確でなければならない。そこで， 関連要因，法則および適用範囲について取りまとめると Table 1 のようになる。しかし, 各ステップにおける法則は, 同表に示すように一部既往の研究で明確とはなっているが, 以下の事項については明確になっていない。

1) 多様な材料および機械条件に対する包括的に成立する押 出成形圧力と速度との定量的な関係

2) 包括的に成立する定量的な圧力と水量比との関係

3) 包括的に成立する定量的な速度と水量比との関係

1) は操作点を定量的に表現するための関係であり，実際 に行う製造における操作点はこの関係上にある。2)および 3) は生産実行中に水量調節・スクリュ一回転数の調節等に 
よって機械の操作条件を変えるための基本情報であり，これ から求められる值により 1) の関係上の位置を確定できると 同時に，単位水量等の変化に対する操作条件の変化を瞬時に 予測することができる。

\section{2 要素技術の提案}

ここでは，プロセス制御フローの要素技術のうち明確とは なっていない上記 1)～3) の項について明らかにする。

まず1)に関しては，Equations(2),(3)および (4)より，操 作点である押出成形圧力 ( P ) と速度 ( V ) との関係は, 次 式のように表現される。

$$
V=\frac{\left(t_{e 0}-t_{c}\right)^{d}}{\left(t_{e 0}-1\right)^{d}} \cdot \frac{n \cdot c}{A} \cdot P^{-d}
$$

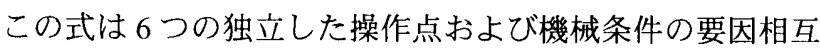
の関係式であり，機戌条件による定数 $\mathrm{c}$ と $\mathrm{d}$ を得ることに よって操作点は決定される。

次に，2)に関しては，Equations(2),(3),(4) および(5)より, $\mathrm{V}$ および $\mathrm{Q}$ を消去すると, 成形圧力 ( P ) と水量比 $\left(\mathrm{W}^{*}\right)$ と の関係は次式のように表現される。

$$
P=\frac{t_{e 0}-t_{e}}{t_{e_{0}-1}} \cdot c^{1 / d} \cdot\left(e \cdot W^{*}+f\right)^{-1 / d}
$$

この式は，押出成形圧力と水量比との関係をバレルおよび ダイという機械条件に関するパラメータを媒介として与える もので，この式の活用によりオンライン中に水量調整によっ て成形圧力を変えることができる。

以上により求められた関係と既往の関係とを合わせて実験 結果にあてはめると, Table 2 のようになった。ここでは, 適用範囲および主要定数についても記している。

Table 2 Equations of relationships between extruding pressure and water content ratio

\begin{tabular}{llllll}
\hline $\begin{array}{l}\text { Barrel } \\
\text { diameter, }\end{array}$ & $\begin{array}{l}\text { Effective } \\
\text { thickness } \\
\text { of barrel, }\end{array}$ & $\begin{array}{l}\text { Kind } \\
\text { of fibers }\end{array}$ & \multicolumn{4}{c}{ Constant of equation } \\
$2 \mathrm{r}(\mathrm{cm})$ & $\mathrm{t} \mathrm{e} 0(\mathrm{~cm})$
\end{tabular}

\begin{tabular}{|c|c|c|c|c|}
\hline $\begin{array}{l}\text { Name of law } \\
\text { [reference] }\end{array}$ & Equation & $\begin{array}{l}\text { Main } \\
\text { variable }\end{array}$ & Main parameter: factor & Object \\
\hline $\begin{array}{l}\text { Plastic processing law } \\
{[1,2]}\end{array}$ & $\tau=a \sigma^{b}$ & $\tau, \sigma(P)$ & $a, b:$ substances, die openings and barrels & $\begin{array}{l}\text { stress conditions } \\
\text { in tapered barrels }\end{array}$ \\
\hline $\begin{array}{l}\text { Productive law } \\
\text { [1] }\end{array}$ & $Q=c P^{-r l}$ & $Q, P(\sigma)$ & $c, d:$ substances and barrels & $\begin{array}{l}\text { production efficiency } \\
\text { and extruding pressure }\end{array}$ \\
\hline $\begin{array}{l}\text { Effective thickness law } \\
{[3,4,5]}\end{array}$ & $\frac{P}{P_{\max }}+\frac{t_{\mathrm{c}}}{t_{\mathrm{co}}}=1$ & $P, t$ & $\begin{array}{l}P_{\text {max }}: \text { substances and mix proportions } \\
t_{0}: \text { geometries of barrels } \\
t_{\mathrm{t}}: \text { geometries of die openings }\end{array}$ & $\begin{array}{l}\text { degree of plastic processing } \\
\text { in extruder }\end{array}$ \\
\hline $\begin{array}{l}\text { Extruding velocity law } \\
\text { [3] }\end{array}$ & $\begin{array}{c}V=n \cdot Q /\left(\zeta \cdot A_{0}\right) \\
(V / Q=n / A)\end{array}$ & $V, Q$ & $\begin{array}{l}n: \text { rotational frequency } \\
\zeta: \text { A/A } 0, \text { die barrel opening ratio } \\
A_{0}: \text { sectional area of barrels } \\
\text { A: sectional area of die openings }\end{array}$ & $\begin{array}{l}\text { extruding velocity } \\
\text { and production efficiency }\end{array}$ \\
\hline $\begin{array}{l}\text { Production efficiency law } \\
\text { [4] }\end{array}$ & $Q=e W^{*}+f$ & $Q, W^{*}$ & $e, f:$ substances and barrels & $\begin{array}{l}\text { production efficiency } \\
\text { and mix proportions }\end{array}$ \\
\hline
\end{tabular}

Table 1 Various laws for presenting operating points of extrusion moulding

Materials and mix proportions

$\downarrow \leftarrow$ Single shear test

Shear characteristics ( cohesion and internal friction coefficient )

$\downarrow \leftarrow$ Plastic processing law for standard extruder and standard die

Extruding pressure under standard extruder $\left(t_{e 0}=2.5\right)$ and standard die $\left(t_{e}=t_{01}\right)$

$\downarrow \leftarrow$ Effective thickness law under standard extruder $\left(t_{00}\right)$ and standard die $\left(t_{0}\right)$

Maximum extruding pressure ( $\left.P_{\max 1}\right)$

$\downarrow \leftarrow$ Another extruder ( effective thickness of barrel; $t_{\mathrm{c} 0}{ }^{\prime}$ )

New relationship between effective thickness $\left(t_{\bullet}\right)$ and extruding pressure $(P)$ under another extruder

$\downarrow \leftarrow$ Effective thickness of another die ( effective thickness; $t_{e z}$ )

Extruding pressure $\left(\mathrm{P}_{2}\right)$ under another extruder and another die

$\downarrow \leftarrow$ Relationship between effective thickness and die barrel opening ratio

Die barrel opening ratio under another extruder and another die

$\downarrow \leftarrow$ Productivity law under another extruder and another die

Conveying rate per revolution

$\downarrow \leftarrow$ Die barrel opening ratio under another extruder and another die

Extruding velocity ( $\mathrm{V}$ ) under another extruder and another die

Figure 1 Flow for predicting operating points ( one way) 


\section{3 断面形状パラメー夕則の提案}

部材の断面形状の各種パラメータのうち, 押出成形圧力に 関連する有効厚さ $\left(\mathrm{t}_{\mathrm{e}}\right)$ と押出成形速度に関連するダイバレ ル開口率 $(\zeta)$ とは互いに独立するものであり，現実に工場 で押出成形を実施する場合は与条件として予め与えられる。 しかし，プロセス制御システムを作動させるためには，採用

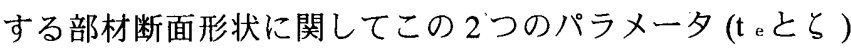
を与えておく必要がある。そこで，バレル径を部材幅（ w ） 一定で部材厚 $(\mathrm{t}$ ) を変化させた場合, 部材厚一定で部材幅 を変化させた場合，ならびに部材断面形状 $6.0 \times 2.5 \mathrm{~cm}$ で 3 つの正方形空洞部をもつシェル厚 (空洞率： $\beta$ ) の異なる場 合を例として示すと, 部材断面に関する有効厚さとダイバレ ル開口率との関係を表す式は Table 3 のようになる。

\section{4. 要素技術の検証}

著者らがこれまでに実施した一連のセメント系材料の押出 成形に関する実験によって得られたデー夕を用いて， Equations(1)〜 (5) ならびに前項「3. 要素技術の提案」で 提案した Equations(6) および(7) で表される要素技術を検証 した。

\section{1 要素技術の検証のためのデータ}

\subsection{1 機械条件}

押出成形機は，Table 4 に示すように，著者らが標準的な 機械として用いてきたバレル径 $5.0 \mathrm{~cm}[1-7]$ と, 部材断面積 のスケールアップに伴うバレル径拡大を考慮したバレル径 $7.5 \mathrm{~cm}$ との 2 種類である。それぞれの押出成形機は，パグミ ル部とバレル部の中間に真空脱気槽を備えている。

ダイ開口形状の諸元を Table 5 に示す。ダイ開口形状は, 部材幅を一定として部材厚を变化させた場合, 部材厚を一定 として部材幅を変化させた場合, 外部形状を一定として空洞 率を 3 方向に変化させた場合とした。

\subsection{2 材料条件}

セメント系押出成形部材の製造に用いる物質は，セメント， 細骨材, 水, 繊維質添加材および増粘剂からなる。セメント として普通ポルトランドセメント ( M 社製 ) ( JIS R 5201 ) を, 細骨材として豊浦標準砂を, 増粘剈としてメチルセルロ 一ス ( S 社製 90SH-4000)を，繊維質添加材としてクリソタ イル 6D ( JIS M 8602 ) をそれぞれ用いた。また, セメント 系押出成形部材の高勒性化の付与が予備実験により確認され た繊維表面を金属酸化物で被覆した親水性化ポリプロピレン 繊維 (SD 社製 以下, 親水性化 PP と記す。) も瀻維質添加材 として用いた。セメントの物性を Table 6 に, 細骨材の物性 を Table 7 に, クリソタイルおよび親水性化 PP の物性を Table 8 にそれぞれ示す。

Table 9 に調合とダイ開口形状との組合わせを示す。セメ ントに対する細骨材の割合(砂セメント比; 以下 $\mathrm{S} / \mathrm{C}$ と記す。) を質量比で 1.00 一定とし, 水量比は繊維質添加材がクリソ タイルの場合は $0.13 \sim 0.25$, 親水性化 PPの場合は $0.13 \sim$
Table 3 Equations of relationships between die barrel opening ratio and effective thickness

\begin{tabular}{rll}
\multicolumn{2}{c}{ Die opening geometry $(\mathrm{cm})$} & \multicolumn{1}{c}{ Equation } \\
\hline $6.0 \times t$ & $(t:$ thickness $)$ & $\zeta=36 t \mathrm{e} / \pi r^{2}(6.0-t \mathrm{e})$ \\
$w \times 2.5$ & $(w:$ width $)$ & $\zeta=6.25 t \mathrm{e} / \pi r^{2}(2.5-t \mathrm{e})$ \\
$6.0 \times 2.5 \quad(\beta:$ hollow ratio $)$ & $\zeta=t \mathrm{e}(8.5+5 \sqrt{5 \beta}) / \pi r^{2}$
\end{tabular}

Table 4 Specifications of extruders

\begin{tabular}{llcccc}
\hline Maker & Model & $\begin{array}{c}\text { Installed } \\
\text { mortar } \\
(\mathrm{kw})\end{array}$ & $\begin{array}{c}\text { Conveying } \\
\text { capacity } \\
(\mathrm{l} / \mathrm{h})\end{array}$ & $\begin{array}{c}\text { Vacuum } \\
\text { pump } \\
(\mathrm{l} / \mathrm{min})\end{array}$ & $\begin{array}{c}\text { Barrel } \\
\text { diameter } \\
(\mathrm{cm})\end{array}$ \\
\hline Honda* & $D E-50$ & 0.75 & $12-25$ & 60 & 5.0 \\
Honda & $D E-75 D$ & 0.75 & $15-40$ & 60 & 7.5 \\
\hline
\end{tabular}

(Note) * This extruder has been used as the standard extruding machine in the authors' ( A. MORI and A. BABA) previous studies.

Table 5 Die opening geometries

\begin{tabular}{cccccc}
\hline $\begin{array}{l}\text { Geometry } \\
\text { of die } \\
(\mathrm{cm})\end{array}$ & $\begin{array}{l}\text { Hollow } \\
\text { ratio } \\
(\%)\end{array}$ & $\begin{array}{l}\text { Barrel } \\
\text { diameter, } \\
2 \mathrm{r}(\mathrm{cm})\end{array}$ & $\begin{array}{l}\text { Area of die } \\
\text { opening, } \\
\mathrm{A}\left(\mathrm{cm}^{2}\right)\end{array}$ & $\begin{array}{l}\text { Die opening } \\
\text { ratio, } \\
\left(\mathrm{A} / \mathrm{A}_{0}\right)\end{array}$ & $\begin{array}{l}\text { Effective } \\
\text { thickness, } \\
\mathrm{t} \mathrm{c}^{(\mathrm{cm})}\end{array}$ \\
\hline $6.0 \times 1.2$ & 0 & 5.0 & 7.20 & 36.7 & 1.00 \\
$6.0 \times 1.5$ & 0 & 5.0 & 9.00 & 45.8 & 1.20 \\
$6.0 \times 2.5$ & 0 & 5.0 & 15.00 & 76.4 & 1.76 \\
$10.0 \times 1.2$ & 0 & 5.0 & 12.00 & 61.1 & 1.07 \\
$6.0 \times 2.5$ & 33.8 & 5.0 & 9.93 & 50.6 & 0.66 \\
$6.0 \times 2.5$ & 45.0 & 5.0 & 8.25 & 42.0 & 0.52 \\
\hline $10.0 \times 2.5$ & 0 & 7.5 & 25.00 & 56.6 & 2.00 \\
$10.0 \times 2.5$ & 33.8 & 7.5 & 16.55 & 37.5 & 0.68 \\
$10.0 \times 2.5$ & 45.0 & 7.5 & 13.75 & 31.1 & 0.53 \\
\hline
\end{tabular}

Table 6 Chemical compositions and properties of Portland cement

\begin{tabular}{|c|c|c|c|c|c|}
\hline \multirow[b]{2}{*}{ Kind } & \multirow[b]{2}{*}{$\begin{array}{l}\text { Density } \\
\left(\mathrm{g} / \mathrm{cm}^{3}\right)\end{array}$} & \multirow{2}{*}{$\begin{array}{l}\text { Specific } \\
\text { surface area } \\
\left(\mathrm{cm}^{2} / \mathrm{g}\right)\end{array}$} & \multicolumn{3}{|c|}{ Setting time } \\
\hline & & & $\begin{array}{c}\text { Water content } \\
(\%)\end{array}$ & $\begin{array}{ll}\text { Initial } & \text { Final } \\
(\mathrm{h}-\mathrm{m}) & (\mathrm{h}-\mathrm{m})\end{array}$ & Stability \\
\hline $\begin{array}{l}\text { Ordinary } \\
\text { Portland } \\
\text { cement }\end{array}$ & 3.16 & 3190 & 28.3 & $2-36 \quad 3-45$ & Good \\
\hline $\begin{array}{l}\text { Compress } \\
3 \mathrm{~d}\end{array}$ & $\begin{array}{l}\text { sive streng } \\
7 \mathrm{~d}\end{array}$ & $\begin{array}{c}\text { gth (MPa) } \\
28 \mathrm{~d} \\
\end{array}$ & $\begin{array}{l}\mathrm{MgO} \\
(\%)\end{array}$ & $\begin{array}{r}\text { Ignition } \\
(\%)\end{array}$ & \\
\hline 14.7 & 24.6 & 41.6 & 1.9 & 0.7 & \\
\hline
\end{tabular}

Table 7 Properties of aggregate

\begin{tabular}{lccccc}
\hline Kind & Density & $\begin{array}{c}\text { Bulk } \\
\text { density } \\
\left(\mathrm{g} / \mathrm{cm}^{3}\right)\end{array}$ & $\begin{array}{l}\text { Ratio of } \\
\text { solid phase } \\
(-)\end{array}$ & $\begin{array}{l}\text { Angle of } \\
\text { repose } \\
(\text { degree })\end{array}$ & $\begin{array}{c}\text { Water } \\
\text { absorption } \\
(\%)\end{array}$ \\
\hline $\begin{array}{l}\text { Standard } \\
\text { sand }\end{array}$ & 2.66 & 1.56 & 0.59 & 37 & 0.6 \\
\hline
\end{tabular}

Table 8 Properties of fiber additives

\begin{tabular}{|c|c|c|c|c|c|c|}
\hline Kind & $\begin{array}{l}\text { Density } \\
\left(\mathrm{g} / \mathrm{cm}^{3}\right.\end{array}$ & Diameter & $\begin{array}{l}\text { Aspect } \\
\text { ratio } \\
(-)\end{array}$ & $\begin{array}{l}\text { Tensile } \\
\text { strength } \\
(\mathrm{MPa})\end{array}$ & $\begin{array}{l}\text { Young's } \\
\text { modulus } \\
(\mathrm{GPa})\end{array}$ & $\begin{array}{r}\text { Elongation } \\
(\%)\end{array}$ \\
\hline 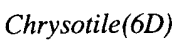 & 2.74 & $0.7 n m$ & - & 1863 & $70-140$ & - \\
\hline $\begin{array}{l}\text { Hydrophilic } \\
\text { polypropylene }\end{array}$ & 0.91 & $17-19 \ddot{~} \mathrm{~m}$ & $158-176$ & 588 & 6.37 & $35-45$ \\
\hline
\end{tabular}

Table 9 Experimental combinations of materials and die opening geometries

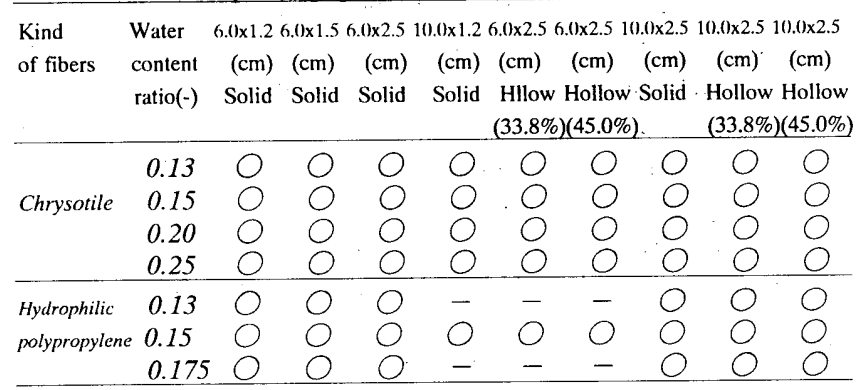


0.175 とした。水セメント比で表すとそれぞれ 0.299〜0.667, 0.299 〜 0.424 である。この水量比の範囲は，滑らかな表面 の部材が得られる水量比であり，この範囲よりも水量比が大 きくなると部材表面には波打ち（Wave）が観察され，逆に 小さくなると犬歯状のひび割れ ( Dog's tooth) が観察される 䉓囲である。増粘剂の添加量は水量比や纎維質添加材の種類 によらずモルタル総質量の 1 質量 \% とした。繊維質添加材 のうちクリソタイルの添加量は, 水量比によらずモルタル総 質量の 5 質量 \% とし, 親水性化 PPについてはクリソタイル と同体積の添加量となるようにした。

\section{2 押出成形圧力と調合との関係}

前項「3. 要素技術の提案」で提案した Equation(7)に基 づいて，押出成形圧力と調合との関係を検証した。その結果 を Figure 2 に示す。Figure 2-a はバレル径が $5.0 \mathrm{~cm}$ の場合を, Figure 2-b はバレル径 $7.5 \mathrm{~cm}$ の場合を示す。図中各プロット は実験值を示し，実線は Equation(7)による計算值を示す。 何れの機械条件および材料条件においても実験值と予測式に よる計算值とは極めて高い整合性を示している。すなわち， 調合およびダイ開口形状を変化させても, Equation(7)によ って調合と成形圧力との関係を予測することができることに なる。

すなわち, 部材製造中に水量比を変化させることによる押 出成形圧力の調整は可能であることになる。また, Table 2 に示すように，各調合における水量比に対する押出成形圧力

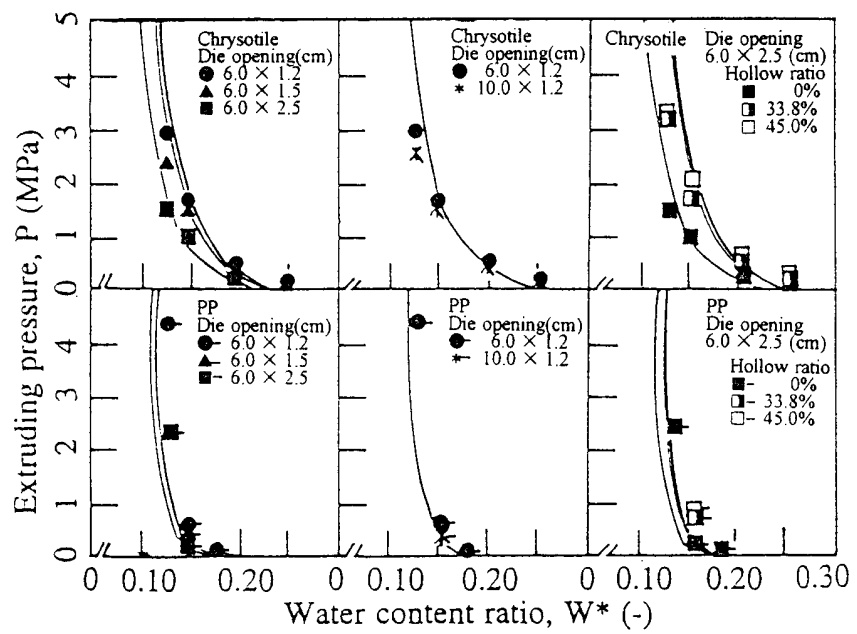

a. barrel diameter $5.0 \mathrm{~cm}$

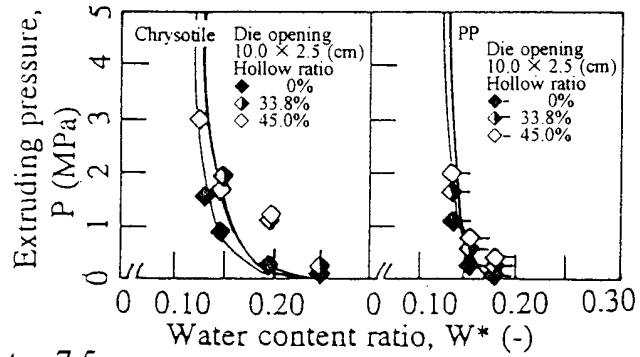

b. barrel diameter $7.5 \mathrm{~cm}$

Figure 2 Coordination between calculated values and experimental ones (water content ratio vs. extruding pressure)
の定数 ( e , f ) が明らかとなっているので, Equation(7) は部 材製造中における成形王力の微調整に有効となる。

\section{3 押出成形速度と調合との関係}

前項「3. 要素技術の提案」で提案した Equation(5)に基 づいて，押出成形速度と調合との関係を検証した。その結果 を Figure 3 に示す。Figure 3-a はバレル径が $5.0 \mathrm{~cm}$ の場合を, Figure 3-b はバレル径 $7.5 \mathrm{~cm}$ の場合を示す。図中各プロット は実験值を示し，実線はEquation(5)による計算值を示す。 何れの機械条件および材料条件においても実験值と予測式に よる計算值とは極めて高い整合性を示している。すなわち， 調合およびダイ開口形状を変化させても， Equation(5)によ って調合と成形速度との関係を予測することができることに なる。

したがって，部材製造中に水量比を変化させることによる 押出成形速度の調整は可能であることになる。また， Table 2 に示すように, 各調合における水量比に対する押出 成形速度の定数 (e, f ) が明らかとなっているので， Equation (5) は部材製造中における成形圧力の微調整に有効となる。

\section{4 押出成形圧力と速度との関係}

前項「3. 要素技術の提案」で提案した Equation(6)に基 づいて，押出成形圧力と速度との関係を検証した。その結果 を Figure 4 に示す。Figure 4-a はバレル径が $5.0 \mathrm{~cm}$ の場合を， Figure 4-b はバレル径 $7.5 \mathrm{~cm}$ の場合を示す。図中各プロット

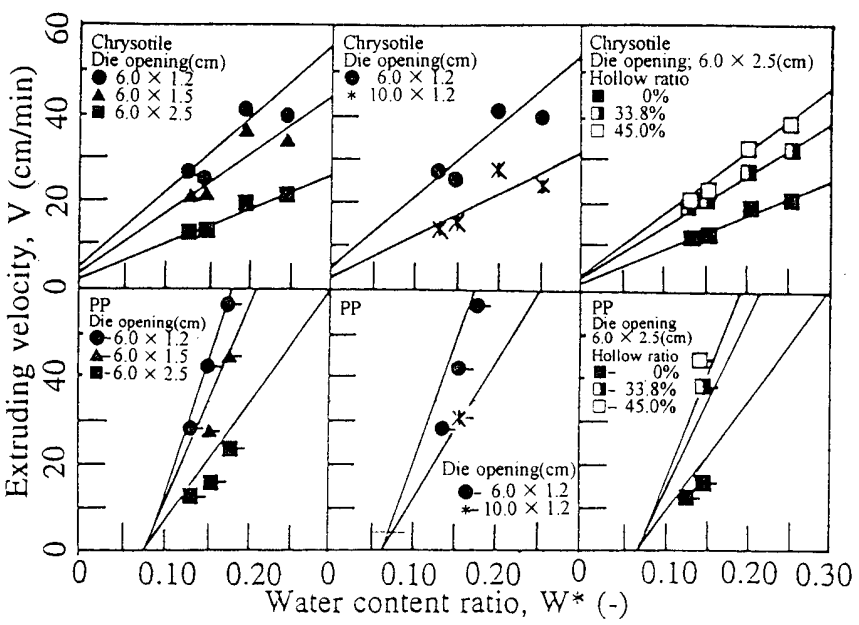

a. barrel diameter $5.0 \mathrm{~cm}$

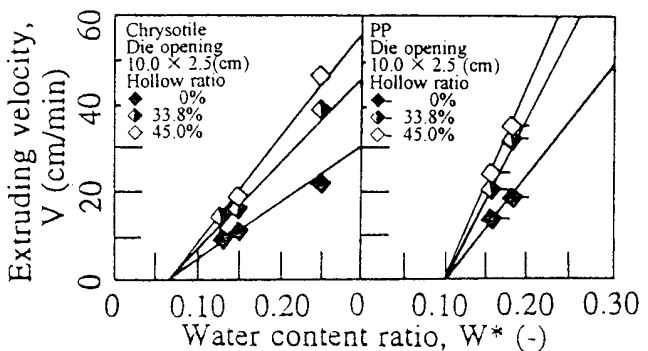

b. barrel diameter $7.5 \mathrm{~cm}$

Figure 3 Coordination between calculated values and experimental ones (water content ratio vs. extruding velocity) 
は実験值を示し，実線はEquation(6)による計算值を示す。 何れの機械条件および材料条件においても実験值と予測式に よる計算值とは極めて高い整合性を示している。すなわち, 調合およびダイ開口形状を変化させても， Equation(6)によ って成形圧力と速度との関係，すな⿰ち，操作点を予測する ことができることになる。

\section{5. ランダムアクセスプロセス制御システム}

前項「4．要素技術の検証」により検証された要素技術を 用いて，多様な材料条件および機械条件に対して，独立した 多変数間に包括的に成立する定量的な関係の全体像を表現し， しかも，材料条件・機械条件の各要素よりランダムにアクセ スできる制御システムとして Figure 5 を提案する。

Figure 5 は，各要素技術の間に成立する関係を相関図を用 いて視覚的に表現したものである。この相関図を用いること により，任意の要素システムからアクセスし操作点を予測す ることが可能である。操作点を予測する手順を図に従って述 ベると以下のようになる。

Figure 5.1 は，「塑性加工則」を示している。用いる押出 成形機によって決定される機械条件下で塑性加工則を求めて おくことにより，一面剪断試験の実施のみで成形圧力を予測 することができる。ここでは，標準的なダイ $(6.0 \times 1.2 \mathrm{~cm})$ およびバレル (直径 $5.0 \mathrm{~cm}$ ) における塑性加工則を示してい る。図中の式は著者らのこれまでの実験により蓄積されたデ 一タ [ 1,2,6および 7] を活用したものであり，それらの豊 富なデー夕を活用することにより，一面剪断試験さえも実施 せずして成形圧力を予測することも可能である。

Figure 5.2 は，「有効厚さ則」を示している。Figure 5.1 よ り予測した標準的なダイ $(\mathrm{t} \mathrm{c}=1.0 \mathrm{~cm})$ における成形圧力(1) と標準的なバレルの有効厚さ $\left(\mathrm{t}_{00}=2.5 \mathrm{~cm}\right)$ より標準的な ダイとバレルにおける有効厚さ則(2)を導き，材料定数である $\mathrm{P}_{\text {max }}$ (3)を求める。求めた $\mathrm{P}_{\text {max }}$ と実際の製造に用いるバレル の有効厚さ ( $\mathrm{t}$ e0 ') とを結んで新たな機械条件における有効 厚さ則(4)を求める。実際の部材製造に用いるダイの有効厚さ $\left(\mathrm{t} \mathrm{e}^{\prime}\right)$ と有効厚さ則(4)との交点が新しい機械条件下での成形 圧力(5)となる。

Figure 5.3 は，操作点にそれぞれ関係する 2 つ機械条件 である「有効厚さとダイバレル開口率との関係」を示してい る。「有効厚さとダイバレル開口率との関係」に用いるダイ の有効厚さ $(\mathrm{t} \mathrm{c})$ を置くとダイバレル開口率(6)が求められる。 求めた值(6)を用いることにより, 成形速度予測へと展開する。 様々な製品断面形状の系に対応したダイ開口形状についての 有効厚さとダイバレル開口率との関係は, Table 3 に既に示 した。

Figure 5.4 は, 「生産効率則」を示している。予め求めて おいた押出成形機についての生産効率則に予測した成形圧力 (5)を置くと, 単位輸送量(7)が求められる。

Figure 5.5 において, Figure 5.3 で予測したダイバレル開 口率(6)と，Figure 5.4 で予測した単位輸送量(7)との交点(8)を 求め, この值(8)と原点とを結ぶ。得られた直線の傾きの逆数
はら/Q であるが，この直線は図中の矢印で示すように，単 位輸送量 ( Q ) とダイバレル開口率（ち）とにようて, 原点 を中心に変化する。実際の押出成形においては直線の傾きの 逆数は小さいので図上での作業を判りやすくするためにこの 傾きの逆数を 10 倍したものを $\mathrm{Q}=10$ との交点(9)として求め, 成形速度則へとつなげる。

Figure 5.6 は「成形速度則」を示している。図中の式は Equation(4) を変形したものであり,この式は成形速度 $(\mathrm{V})$ と Figure 5.5 で求められた $10 \zeta / \mathrm{Q}$ との積は, スクリュー 回転数 ( n ) およびバレル断面積 ( A n ) より算出される 10 n /A。と等しいことを示している。ここで横軸は, Figure 5.5 で求められたら/Q を 10 倍としたものとする。 Figure 5.5 で 求められた交点(9)に対応する $10 \zeta / \mathrm{Q}$ の值を Figure 5.5 の横 軸に置く。この時の同図中に示す実線との交点(10)して，そ の時の成形速度が得られる。

以上のような手順により，操作点は Figure 5.7 に示すよう に Figure 5.4 における成形圧力(7)と Figure 5.6 における成形 速度10との交点(11)となる。

この相関図は, それぞれの要素の何れの部分からもアクセ スできるものであり，製造現場におけるオンライン修正技術 の基礎となるものである。

\section{6. 結論}

セメント系押出成形部材の製造において，機械条件と材料

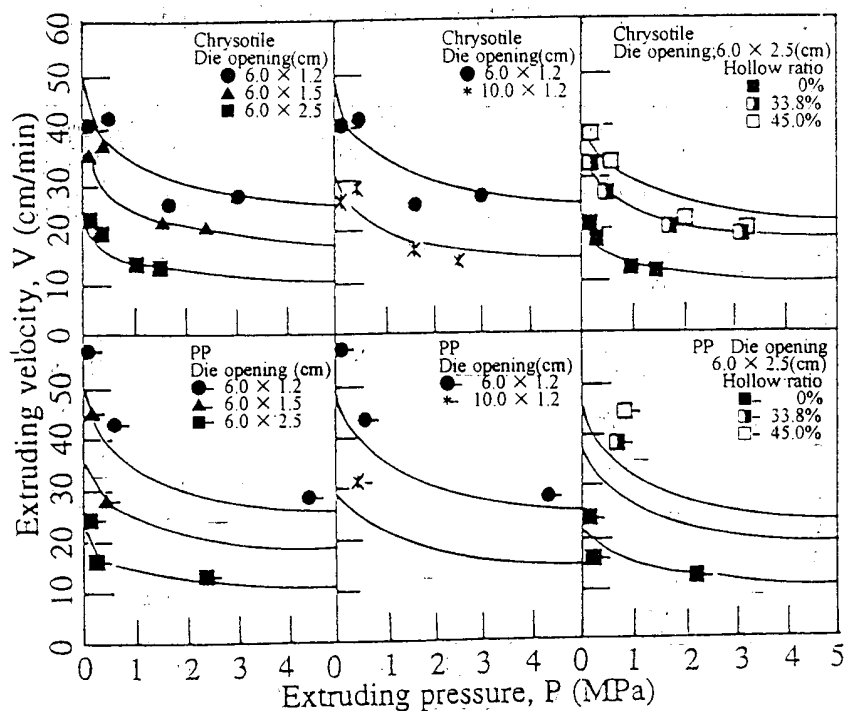

a. barrel diameter $5.0 \mathrm{~cm}$

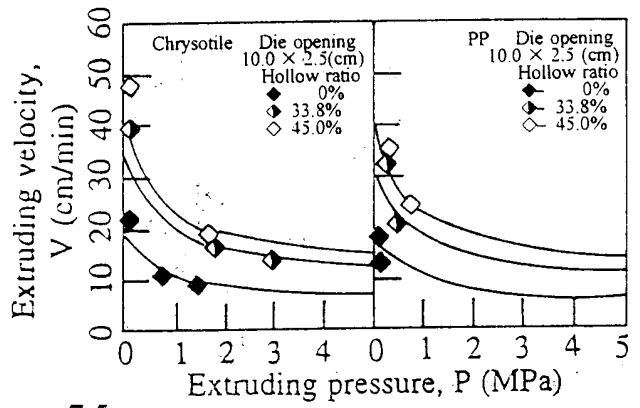

b. barrel diameter $7.5 \mathrm{~cm}$

Figure 4 Coordination between calculated values and experimental ones (Operating points) 
条件とを任意に変化させた 場合における総合的なプロ セス制御システムの開発を 目的に, プロセス制御フロ 一の各ステップにおける要 素技術を提案した。提案し た要素技術をセメント系材 料の押出成形に関する一連 の実験デー夕に基づいて検 証したところ，計算值と実 験值とはよく一致した。こ の結果から, 何れの要素技 術からもランダムにアクセ ス可能な, セメント系押出 成形部材のプロセス制御シ ステムを開発した。

\section{謝辞}

本研究の遂行にあたり，建設 省建築研究所 黃方山美穗氏, （株）日本製鋼所 時久昌吉氏 および林政枝氏, 昭和電工 （株）松永豊治氏および黒住忠 利氏に協力頂いた。記して謝意 を表す。

\section{[ 参考文献 ]}

[1] 守 明子・馬場明生：セメン 卜系建築材料の押出成形にお ける製造プロセス制御方法の 開発，日本建築学会構造系論 文集，No.456，pp.1-10， 1994 年 2 月

[2] 守 明子・馬場明生 ; 一面剪 断試験によるセメント系建築 材料の押出成形性の評価方法, 日本建築学構造系論文集, No.461， pp.1-10， 1994 年. 7 月

[3] 守明子 - 馬場明生 - 眞方山 美穂・䦝口昌利・時久昌吉 ; セメント系押出成形部材の製 造特性および曲げ特性に及ほ すダイ開口形状の影響に関す る研究（その1）～(その5), 日本建築学会九州支部研究報 告, 第 36 号, pp.165-184, 1997 年 3 月

[4] 守明子 - 馬場明生 - 黃方山 美穂 - 堀口昌利 - 時久昌吉 ; セメント系材料の押出成形における製造プロセス制御方法の開発（そ の 3) 〜 (その 7), 日本建築学会大会学術講演梗概集, pp.805-814, 1997 年 9 月

[5] 馬場明生・守 明子 ; セメント系材料の押出成形における成形圧力を 予測するための夕゙イ開口形状の幾何学的評価方法の提案, 日本建築学 会構造系論文集, No.501， pp.1-6，1997 年 11 月
Extruding pressure, $\mathrm{P}(\mathrm{MPa})$

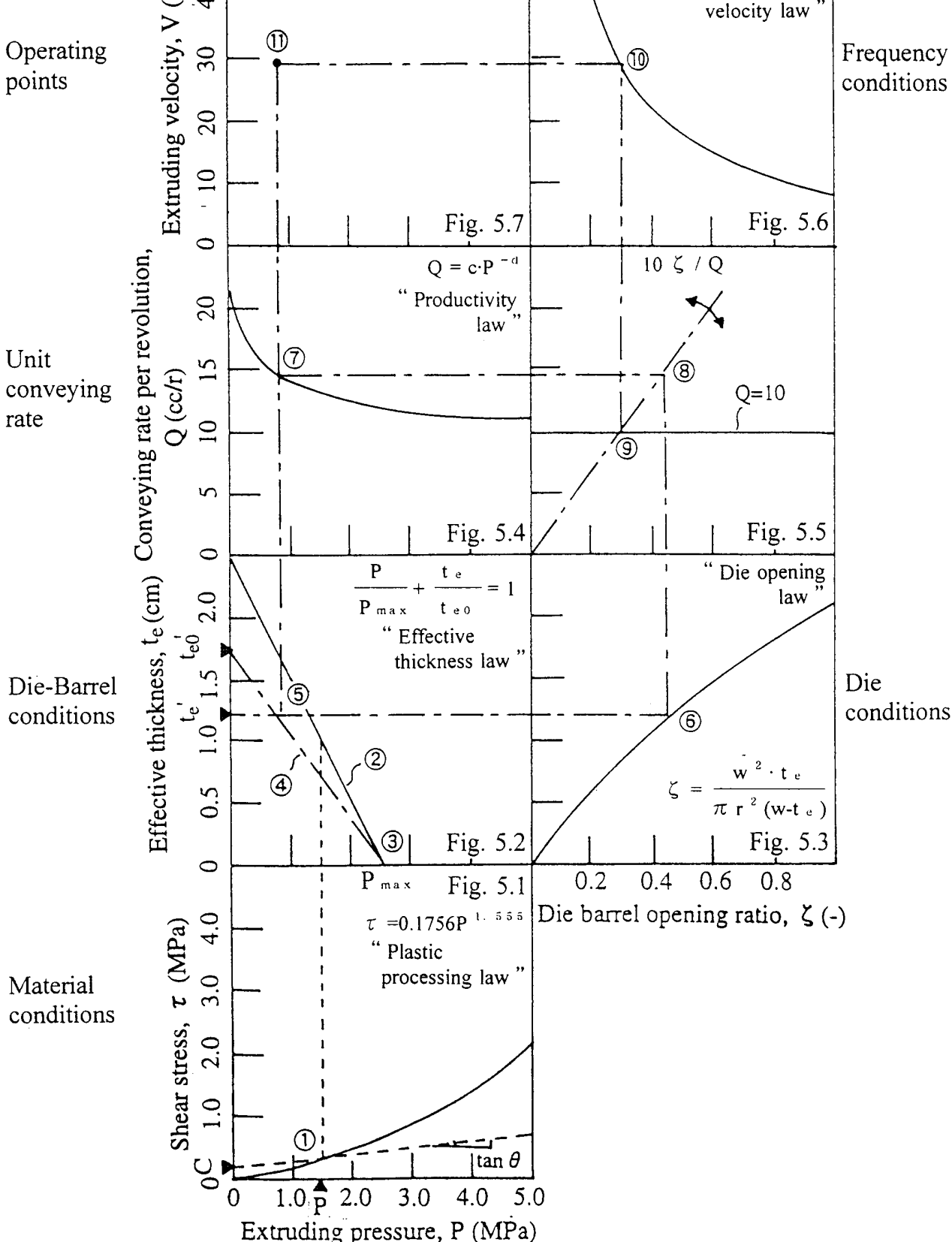

Figure 5 Random access system for predicting operating points
[6] 守 明子・馬場明生 : 新素材繊維を混入したセメント系材料の押出成 形性，日本建築学会構造系論文集，No.484，pp.1-6，1996 年 6 月

[7] 守 明子・馬場明生 ; セメント系材料の押出成形におよぼす骨材最大 寸法の影響, 日本建築学会構造系論文集, No.491， pp.1-6， 1997 年 1 月 